\title{
Counter flow induced draft cooling tower option for Supercritical Carbon Dioxide Brayton Cycle
}

\author{
Sandeep R. Pidaparti \\ Georgia Institute of Technology, George W. Woodruff School of Mechanical Engineering \\ Atlanta, Georgia 30332, USA \\ Anton Moisseytsev \\ Argonne National Laboratory \\ 9700 South Cass Avenue, Argonne, Illinois 60439, USA \\ James J. Sienicki \\ Argonne National Laboratory \\ 9700 South Cass Avenue, Argonne, Illinois 60439, USA \\ Devesh Ranjan \\ Georgia Institute of Technology, George W. Woodruff School of Mechanical Engineering \\ Atlanta, Georgia 30332, USA \\ devesh.ranjan@me.gatech.edu
}

\section{ABSTRACT}

A simplified qualitative analysis was performed to investigate the possibility of using counter flow induced draft cooling tower option to reject heat from the supercritical carbon dioxide Brayton cycle for Advanced Fast reactor (AFR)-100 and Advanced Burner reactor (ABR)-1000 plants. A Code was developed to estimate the tower dimensions, power and water consumption, and to perform economic analysis. The code developed was verified against a vendor provided quotation and is used to understand the effect of ambient air and water conditions on the design of cooling tower. The calculations indicated that there exists optimum water conditions for given ambient air conditions which will result in minimum power consumption, thereby increasing the cycle efficiency. A cost-based optimization technique is used to estimate the optimum water conditions which will improve the overall plant economics. A comparison of different cooling options for the $\mathrm{S}-\mathrm{CO}_{2}$ cycle indicated that the cooling tower option is a much more practical and economical option compared to the dry air cooling or direct water cooling options. 


\section{INTRODUCTION}

For energy conversion in the Generation IV Nuclear power plants, U.S. Department of Energy is considering the supercritical $\mathrm{CO}_{2}\left(\mathrm{~S}_{-}-\mathrm{CO}_{2}\right)$ Brayton cycle as a promising alternative to the conventional Rankine steam cycle and recuperated gas Brayton cycle. The $\mathrm{S}-\mathrm{CO}_{2}$ cycle takes advantage of high density of fluid near the critical point to reduce the compression work, and hence increase cycle efficiency in comparison to recuperated gas Brayton cycle. In addition to higher cycle efficiency, the $\mathrm{S}-\mathrm{CO}_{2}$ Brayton cycle also offers additional benefits such as reduction in size and number of components, and, for sodium-cooled advanced convertors, eliminating risk of potential sodium-water interaction. One of the very important aspect to consider for successful operation of this cycle is selection of cheap, feasible, and reliable option to reject the heat from the cycle.

There are numerous ways to reject heat from power generation plants. One of the traditional options is to circulate water from a nearby water source like river, lake, pond etc. which acts as an ultimate heat sink. The use of this direct water cooling option could be severely restricted due to the environmental policies and scarcity of water sources in some locations. Alternatively, the dry air cooling option can be used with air as the ultimate heat sink. However, poor heat transfer and transport properties of air in comparison with water increase the air circulation power requirements and the required heat transfer surface area. Recent study by Moisseytsev et al. [1] concluded that even though the air cooling option is feasible at least a $40 \%$ increase in electricity price could be expected by implementing air cooling for an $\mathrm{S}-\mathrm{CO}_{2}$ cycle in conjunction 
with the Heatric heat exchanger technology [2]. Another alternative to these two options would be the use of the cooling towers. In this approach, $\mathrm{CO}_{2}$ is still cooled by the water flow in the cooler, but the heat from water is ultimately rejected to air in the cooling towers. Although this method doesn't eliminate the use of water completely it is only required to compensate for water loss due to evaporation in the cooling towers. Considering the advantages and disadvantages of different type of wet cooling towers, counter flow induced draft cooling towers offer benefits like compactness, better control over water temperature for the $\mathrm{S}-\mathrm{CO}_{2}$ Brayton cycles. Hence, these towers are selected for the current study. A simple schematic of the cooler and the counter flow induced draft cooling tower are shown in Fig. 1. Also shown in the figure are key components of the cooling tower which include fill material, water-basin, drift eliminators, louvers, nozzles, fans, and circulating pump.

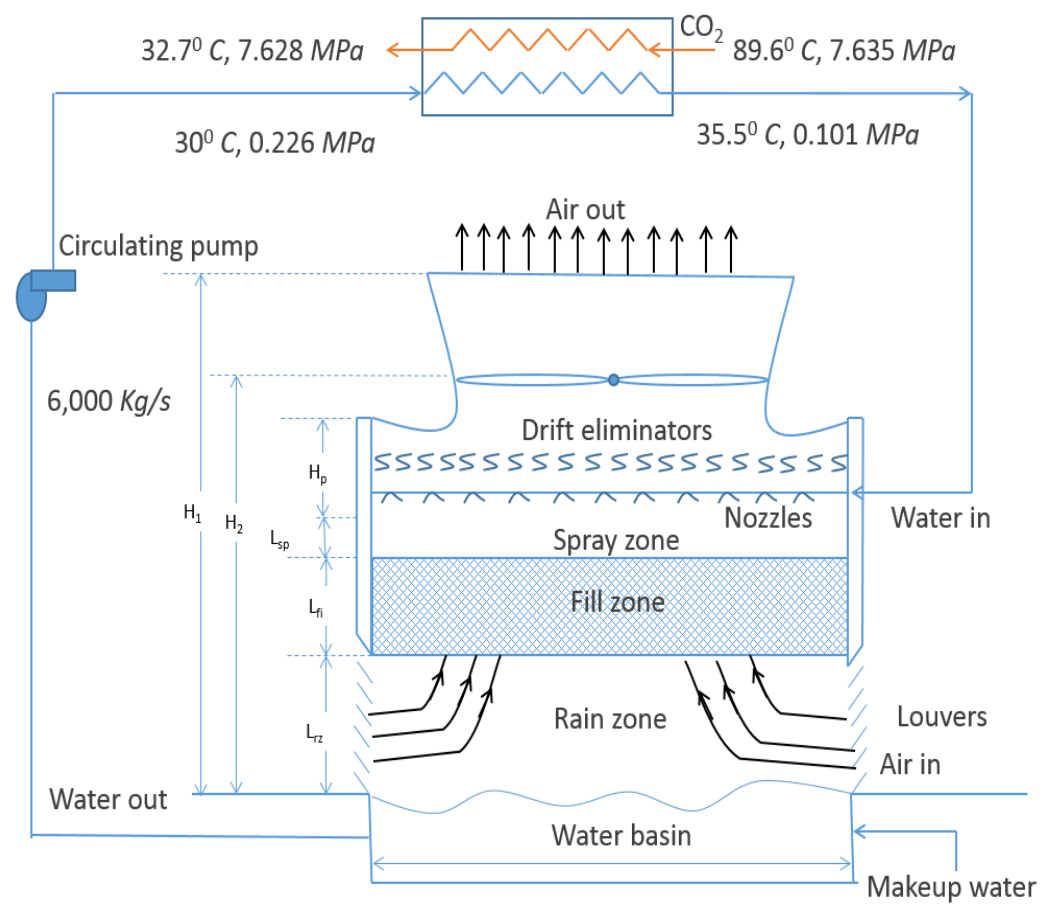

Fig. 1. Schematic of the cooler and counter flow induced draft cooling tower 
The purpose of the current work is to analyze different aspects of using counter flow induced draft cooling tower option to reject heat from the $\mathrm{S}-\mathrm{CO}_{2}$ Brayton cycles and compare these calculations to the direct water cooling and dry air cooling options. Analysis was performed for $\mathrm{S}-\mathrm{CO}_{2}$ cycles developed for advanced fast reactor (AFR-100) and advanced burner reactor (ABR-1000) reactor applications [3], [4]. Detailed calculations for the AFR-100 plant will be presented and the ABR-1000 plant is used for comparison between different cooling options. The reference design conditions for both these power plants are obtained from the Plant Dynamics Code (PDC) developed at Argonne National Laboratory (ANL) [5] and are tabulated in Table. 1.

Table. 1. Reference design conditions for AFR-100 and ABR-1000 plants

\begin{tabular}{|c|c|c|c|}
\hline & Power plant & AFR-100 & ABR-1000 \\
\hline \multirow{4}{*}{ Cycle conditions } & Reactor power $\left(\mathrm{MW}_{\text {th }}\right)$ & 250 & 1000 \\
\cline { 2 - 4 } & Electrical output $\left(\mathrm{MW}_{\mathrm{e}}\right)$ & 104.8 & 400.3 \\
\cline { 2 - 4 } & Cycle efficiency $(\%)$ & 42.27 & 40.26 \\
\hline \multirow{5}{*}{ Cooler conditions } & $\mathrm{CO}_{2}$ inlet temperature $\left({ }^{\circ} \mathrm{C}\right)$ & 89.6 & 87.3 \\
\cline { 2 - 4 } & $\mathrm{CO}_{2}$ outlet temperature $\left({ }^{0} \mathrm{C}\right)$ & 32.8 & 32.7 \\
\cline { 2 - 4 } & $\mathrm{CO}_{2}$ pressure drop $(\mathrm{MPa})$ & 0.007 & 0.009 \\
\cline { 2 - 4 } & Water inlet temperature $\left({ }^{0} \mathrm{C}\right)$ & 30 & 30 \\
\cline { 2 - 4 } & Water outlet temperature $\left({ }^{\circ} \mathrm{C}\right)$ & 35.5 & 36.8 \\
\cline { 2 - 4 } & Water flow rate $(\mathrm{kg} / \mathrm{s})$ & 6,000 & 20,000 \\
\cline { 2 - 4 } & Water pressure drop $(\mathrm{MPa})$ & 0.125 & 0.104 \\
\cline { 2 - 4 } & Cooler thermal load $(\mathrm{MW})$ & 137.2 & 569.2 \\
\hline
\end{tabular}

\section{COOLING TOWER THEORY}

Heat and mass transfer in a cooling tower occurs in three zones namely; spray zone, fill zone, and the rain zone as shown in Fig. 1. However, more than $90 \%$ of the heat transfer occurs in the fill zone, and also a recent study by Quershi and Zubair [6] 
suggested that the error in prediction of tower volume due to exclusion of spray and rain zones in their model is about $6.5 \%$. It was also shown that when the spray and rain zones are included their model, which directly solved the basic governing equations with any assumptions, resulted in $2.65 \%$ error compared to the experimental data of Simpson and Sherwood [7]. Hence, the spray and rain zones are not explicitly modeled in the current work. The governing equations for the fill zone were developed by Merkel [8] based on simplifying assumptions as stated below

1) Air exiting the cooling tower is saturated (100\% relative humidity).

2) Lewis factor, $L e=h_{c} / C_{p m a} h_{d}$ relating heat and mass transfer is assumed to be equal to 1. Lewis factor is typically measured to be in the range of 0.85-0.9 [9].

3) The evaporation losses are neglected during the energy balance.

Equations (1) and (2) are obtained by performing energy and mass balance on the control volume shown in Fig. 2 and using the assumptions stated above. Equation (1) represents the change in the enthalpy of air-water vapor mixture and Equation (2) represents the change in water temperature along the tower height. In Fig. 2, it should be noted that the water stream is flowing downwards in counter flow with the air stream.

$$
\begin{gathered}
\frac{d i_{m a}}{d z}=\frac{h_{d a_{f i}} A_{\text {floor }}}{\dot{m}_{a}}\left(i_{\text {masw }}-i_{\text {ma }}\right) \\
\frac{d T_{w}}{d z}=\frac{\tilde{m}_{a}}{\dot{m}_{w}} \frac{1}{c_{p w}} \frac{d i_{m a}}{d z}
\end{gathered}
$$

Equations (1) and (2) can be combined into a single equation and integrated from inlet to outlet of the fill zone to obtain the well-known Merkel equation [10], 


$$
M e=\frac{h_{d} a_{f i} L_{f i l l}}{G_{w}}=\int_{T_{w o}}^{T_{w i}} \frac{c_{p w} d T_{w}}{\left(i_{\text {masw }}-i_{\text {ma }}\right)}
$$

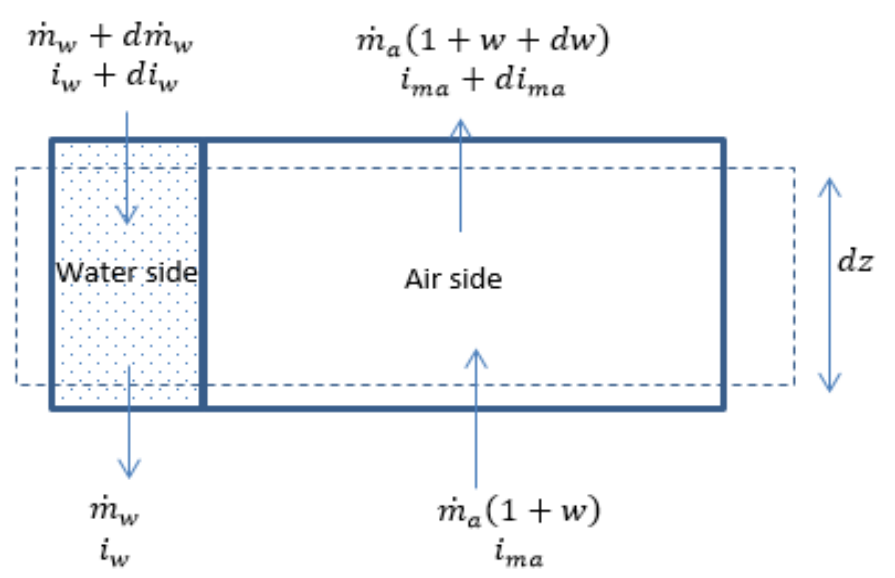

Fig. 2. Control volume of counter flow fill zone configuration

Equation (3) is traditionally used to estimate the cooling tower dimensions if the mass transfer coefficient $\left(h_{d}\right)$ and area density of fill $\left(a_{f i}\right)$ are known. Due to complex nature of two-phase flow in the fill, it is extremely difficult to measure $h_{d}$ and $a_{f i}$ individually. Fortunately, these two exist as a product in Equation (3) and individual values are not needed for design calculations. Although the Merkel theory is widely accepted and used by cooling tower designers, it can be argued that the assumptions used to derive Equation (3) does not accurately represent the physics of heat and mass transfer in the fill zone. However, the main purpose of this work is to qualitatively understand the various aspects of using a cooling tower rather than accurately designing cooling towers for $\mathrm{S}-\mathrm{CO}_{2}$ Brayton cycles. 


\section{DESIGN PROCEDURE}

A code was developed to understand the effect of water and ambient air conditions on the size of cooling tower as well as to perform economic analysis in conjunction with the ANL Plant Dynamics Code. The equations described in this section are modeled in Engineering Equation Solver (EES) [11]. The code developed is verified by comparing the calculations to a quotation obtained from Delta Cooling Towers, Inc. [12] for the conditions specified in their quotation.

\section{Estimation of optimum $\dot{m}_{w} / \dot{m}_{a}$}

For a given set of water conditions and ambient air conditions there exists an optimum value of $\dot{m}_{w} / \dot{m}_{a}$ which results in minimum construction and operating costs. Leeper [13] reported that the optimum $\dot{m}_{w} / \dot{m}_{a}$ can be estimated using Equation (5) within $10 \%$ error by approximating the optimum air outlet temperature, $T_{a o}$ in Equation (4), as the average of hot and cold water temperature entering and exiting the tower,

$$
\begin{gathered}
T_{a o}=\frac{T_{w i}+T_{w o}}{2} \\
\frac{\dot{m}_{W}}{\dot{m}_{a}}=\frac{i_{m a o}-i_{m a i}}{c_{p w}\left(T_{w i}-T_{w o}\right)}
\end{gathered}
$$

\section{Merkel number (Me)}

For known water conditions, the tower Merkel number is solved numerically using the Chebyshev four point numerical integration method as shown in Equation (6).

$$
M e=C_{p w} \int_{T_{w o}}^{T_{w i}} \frac{C_{p w} d T_{W}}{\left(i_{m a s w}-i_{m a}\right)}=\frac{C_{p w}\left(T_{w i}-T_{W o}\right)}{4}\left(\frac{1}{\Delta i_{1}}+\frac{1}{\Delta i_{2}}+\frac{1}{\Delta i_{g i}}+\frac{1}{\Delta i_{4}}\right)
$$

Where,

$$
\Delta i_{1}=\text { value of } i_{\text {masw }}-i_{\text {ma }} \text { at } T_{\text {wo }}+0.1\left(T_{\text {wi }}-T_{\text {wo }}\right)
$$


$\Delta i_{2}=$ value of $i_{\text {masw }}-i_{\text {ma }}$ at $T_{\text {wo }}+0.4\left(T_{\text {wi }}-T_{\text {wo }}\right)$

$\Delta i_{3}=$ value of $i_{\text {masw }}-i_{\text {ma }}$ at $T_{\text {wo }}+0.6\left(T_{\text {wi }}-T_{\text {wo }}\right)$

$\Delta i_{4}=$ value of $i_{\text {masw }}-i_{\text {ma }}$ at $T_{\text {wo }}+0.9\left(T_{\text {wi }}-T_{\text {wo }}\right)$

\section{Estimation of floor area $\left(\boldsymbol{A}_{\text {floor }}\right)$}

It is a common practice to use a certain number of small cells instead of a single large cell to reduce the total power consumption and to provide better temperature control. Lilly [14] collected information regarding different cell types and their specifications commonly used by the cooling tower manufacturers. These cells are classified based on cell sizes and blower power consumption. Choosing different cells will result in different floor area and total power consumption. Using the smaller cell size will increase the required floor area of the cooling tower but will reduce the power consumption and vice-versa. The dimensions of the cell chosen for this study are length (7'9-3, $[2.38 \mathrm{~m}])$, width $\left(18^{\prime} 1^{\prime \prime \prime},[5.52 \mathrm{~m}]\right)$, height $\left(10^{\prime} 2^{\frac{3}{4}},[3.12 \mathrm{~m}]\right)$ and the power vs flow rate specifications of its blower are shown in Table2.

Table. 2. Power vs Flowrate of the blower used in the cooling tower cells

\begin{tabular}{|c|c|c|}
\hline Tower & Flowrate $\left(\mathrm{cfm}\left[\mathrm{m}^{3} / \mathrm{s}\right]\right)$ & Blower power (HP $[\mathrm{KW}])$ \\
\hline 1 & $70,800[33.41]$ & $10[7.456]$ \\
\hline 2 & $80,750[38.10]$ & $15[11.185]$ \\
\hline 3 & $88,300[41.69]$ & $20[14.913]$ \\
\hline 4 & $95,000[44.83]$ & $25[18.642]$ \\
\hline
\end{tabular}

As can be seen from Table 2, operating the tower in different flow regimes will result in different power consumption and hence, will demand the required floor area accordingly. As a result of this, two extreme options are possible for the chosen cell. 


\section{Lowest power consumption option}

In this option, lowest possible air flow rate per cell $(70,800 \mathrm{cfm})$ is selected from Table 2 . This will reduce the power consumption per cell but will increase the total number of cells, and hence floor area required to achieve the desired performance. Number of cells required for this option is calculated as,

$$
N_{\text {cells }}^{l p c o}=\frac{Q_{\text {ano }}}{70800}
$$

\section{Lowest footprint option}

In this option, highest possible air flow rate per cell $(95,000 \mathrm{cfm})$ is selected from Table 2. This option will result in highest power consumption and smallest tower footprint/cost. Number of cells required is calculated as,

$$
N_{\text {cells }}^{l f o}=\frac{Q_{a 0}}{95000}
$$

Where, $\dot{Q}_{a o}$ is the total required volumetric flow rate of air to achieve the desired performance and is calculated from the known air mass flow rate from Equation (5),

$$
\dot{Q}_{a 0}=\frac{\tilde{m}_{a}}{\rho_{a 0}}
$$

It should be noted that outlet air density is used to estimate the required volumetric flow rate of air in Equation (9) because the fan is located at the exit for an induced draft cooling tower. Once the required number of cells is calculated for each option, the required floor area is calculated by multiplying number of cells and area of each cell, which is equal to $7{ }^{\prime} \frac{5}{8}{ }^{\prime \prime} \times 18^{\prime} 1^{\frac{1}{4}}$ 


\section{Estimation of fill height $\left(L_{\text {fill }}\right)$}

For a given thermal load, required length of a heat exchanger will depend on the surface area and the material used for construction of the heat exchanger. Similarly, the required fill height for a cooling tower will depend on the type of fill used for construction. As reported in the literature, three types of fills namely splash, trickle, and film are most commonly used. Each of these fills have different mass transfer coefficients, area density characteristics and empirical correlations are needed for estimation of fill height. Kloppers et al. [15] performed experiments to investigate these fill types and proposed correlations to predict the Merkel number (Me) for each type.

Merkel number for splash fill is given as,

$$
\frac{\text { Me }}{L_{\text {fill }}^{\text {splash }}}=0.249013 G_{w}^{-0.464089} G_{a}^{0.653578}
$$

Merkel number for trickle fill is given as,

$$
\frac{M e}{L_{f i l l i}^{\text {trickie }}}=0.81707 G_{w}^{-0.581055} G_{a}^{0.670746}
$$

Merkel number for film fill is given as,

$$
\frac{M e}{L_{\text {fill }}^{f \text { film }}}=0.996604 G_{w}^{-0.469512} G_{a}^{0.790386}
$$

Where, $G_{w}$ and $G_{a}$ are the water and air mass fluxes respectively and are defined as,

$$
\begin{aligned}
& G_{w}=\frac{\dot{m}_{w}}{A_{\text {floor }}} \\
& G_{a}=\frac{\dot{m}_{a}}{A_{\text {floor }}}
\end{aligned}
$$

Merkel number estimated according to Equation (6) is used in the above equations to estimate the required fill height for a known set of water and ambient air conditions. 
Once the fill height is known, heights of rain zone and spray zone are calculated as reported by Leeper [13],

$$
\begin{gathered}
L_{r z}=L_{f i n} \\
L_{s p}=0.5 L_{f i n}
\end{gathered}
$$

The cooling tower head $\left(H_{\text {tower }}\right)$ is then calculated as the sum of the heights of these three zones.

$$
H_{\text {tower }}=L_{s p}+L_{\text {fill }}+L_{r z}=2.5 L_{\text {fill }}
$$

Leeper [13] suggested to add an additional $10^{\prime}$ to the value calculated from Equation (17) so as to compensate for the assumption made regarding spray and rain zones.

\section{Water consumption rate}

There are three major sources of water loss in a wet cooling tower as described in this section. Total water consumption rate is estimated as the sum of these three losses.

\section{Evaporation losses $(E)$}

As the water is cooled in the cooling tower, portion of water gets evaporated into the air stream. The difference in amount of water vapor in the entering and exiting air streams is calculated to find out the amount of water evaporated,

$$
E=\dot{m}_{\alpha}\left(w_{o}-w_{i}\right)
$$

Blow-down losses $(B)$

As the water evaporates, solids and chemical matter accumulates in the cooling water. If ignored, this will result in severe corrosion and chemical build up affecting the performance of the tower in long run. Hence, some amount of circulating water needs 
to be replaced by fresh water to keep the impurities at acceptable levels. These losses are known as Blow-down losses and are estimated as [16],

$$
B=\frac{E}{\operatorname{CoC}-1}
$$

Where, $C O C$ is the cycles of concentration and is a measure of concentration of impurities in the cooling tower water in comparison to concentration of impurities in the make-up water. Cycles of concentration is typically limited from 3-7 and value of 3 is used in this study for an upper estimate of blow-down losses.

Drift losses $(W)$

Some of the water droplets get carried away by the air stream and these losses are known as drift losses. With use of drift eliminators as shown in Fig. 1, these losses can be minimized to within $0.2-0.5 \%$ of the total water flow rate. In this work, upper bound of $0.5 \%$ is used as a conservative assumption,

$$
W=0.005 \dot{m}_{w}
$$

\section{Power consumption}

Power required to operate the cooling tower is comprised of two parts namely, water pumping power and the air blower power. The power required to operate the water pump is calculated as,

$$
P_{\text {pump }}=\frac{\tilde{m}_{W} H_{p} g}{\eta_{p u m p}}
$$

Where, $H_{p}$ is the net required pumping head and is equal to the sum of required head in the cooling tower $\left(H_{\text {tower }}\right)$ and the cooler $\left(H_{\text {cooler }}\right)$. The cooling tower head is calculated from Equation (17) with the addition of the recommended 10' of head. The cooler head is the head required to overcome the water side pressure drop across the cooler 
expressed in the units of water column and is obtained from the ANL Plant Dynamics Code. In Equation (21), efficiency of water pump $\left(\eta_{\text {pump }}\right)$ is assumed to be $90 \%$.

Blower power for the lowest power consumption and lowest footprint options described in earlier sections is calculated from Equations (22) and (23) respectively.

$$
\begin{aligned}
& P_{\text {blower }}^{\text {lpco }}=10[H P] \cdot N_{\text {cells }}^{\text {lpco }} \\
& P_{\text {blower }}^{\text {lfo }}=25[H P] \cdot N_{\text {cells }}^{\text {lfo }}
\end{aligned}
$$

\section{Estimation of cooling tower cost}

Empirical correlations are proposed in literature [13], [17] to estimate the cooling tower cost. These correlations can be used to estimate cost of a single cell. Cost of the cooling tower for the lowest power consumption and lowest footprint options is calculated from Equations (24) and (25) respectively.

$$
\begin{aligned}
& \text { Cost }_{\text {tower }}^{\text {lpco }}=N_{\text {cells }}^{\text {lpco }} \text { Cost } t_{\text {cell }} \\
& \text { Cost }_{\text {tower }}^{\text {lfo }}=N_{\text {cells. }}^{\text {lfo }} \text {. Cost } t_{\text {cell }}
\end{aligned}
$$

Where, Cost $_{\text {cell }}$ is the price of each cell and is equal to $\$ 37,370$ as per the quotation obtained from Delta Cooling Towers, Inc. This approach will predict different costs for both the options based on the required number of cells.

\section{DESIGN CALCULATIONS}

Engineering Equation Solver (EES) code developed based on Equations (4) through (25) was verified by comparing the calculations to the quotation obtained from Delta Cooling Towers, Inc. [12] for the conditions specified in their quotation. These calculations are presented in Table 3. It should be noted that the quotation obtained 
from Delta Cooling Towers, Inc. is for the lowest footprint option and these values match well with the code predictions. The manufacturer used a 30HP fan per cell whereas the code uses 25HP fan per cell which explains why the code slightly underestimates the required blower power. Required number of cells and the floor area matches extremely close to the vendor quotation indicating that the assumption made regarding the optimum $\dot{m}_{w} / \dot{m}_{a}$ is valid. The table also compares the different fill types described earlier. As can be seen from the table, fill height, and hence water pumping power are much smaller using the film fill compared to splash or trickle fill types. Although the exact fill type used by the manufacturer is unknown, their specifications are closer to the film fill calculations. Hence, film fill is used for all the calculations reported from hereon.

Table. 3. Comparison of code calculations to the manufacturer quotation

\begin{tabular}{|c|c|c|c|c|c|}
\hline Variable & Delta & \multicolumn{3}{|c|}{$\begin{array}{c}\text { Calculated } \\
\text { (Lowest footprint) }\end{array}$} & $\begin{array}{c}\text { Calculated } \\
\text { (Lowest Power) }\end{array}$ \\
\hline Number of cells & 84 & \multicolumn{3}{|c|}{83} & 111 \\
\hline Water mass flow rate $[\mathrm{kg} / \mathrm{s}]$ & 4,900 & \multicolumn{3}{|c|}{4,900} & 4,900 \\
\hline Water inlet temperature $\left[{ }^{\circ} \mathrm{C}\right]$ & 35.78 & \multicolumn{3}{|c|}{35.78} & 35.78 \\
\hline Water outlet temperature $\left[{ }^{\circ} \mathrm{C}\right]$ & 28.88 & \multicolumn{3}{|c|}{28.88} & 28.88 \\
\hline Wet bulb temperature $\left[{ }^{\circ} \mathrm{C}\right]$ & 25.55 & \multicolumn{3}{|c|}{25.55} & 25.55 \\
\hline & & Splash & Trickle & Film & Film \\
\hline Blower power [MW] & 1.88 & 1.545 & 1.545 & 1.545 & 0.8295 \\
\hline Pump power [MW] & 0.182 & 0.7415 & 0.2634 & 0.1588 & 0.1792 \\
\hline Fill height $[\mathrm{m}]$ & $\sim 1.3$ & 5.553 & 1.973 & 1.167 & 1.282 \\
\hline Floor area $\left[\mathrm{m}^{2}\right]$ & 1147 & 1088 & 1088 & 1088 & 1459 \\
\hline Cooling tower cost $[\$] \times 10^{6}$ & 3.139 & \multicolumn{3}{|c|}{3.1017} & 4.148 \\
\hline
\end{tabular}

For the conditions described in the table, lowest power consumption and lowest footprint options are compared. The required number of cells, floor area, and tower 
cost for lowest power consumption are about 33\% more whereas, the power consumption is about $40 \%$ less compared to the lowest footprint option. Hence, it is important to understand which option is more economical to the plant and is explained in more detail later.

\section{Effect of ambient air conditions}

Since ambient air conditions (wet bulb and dry bulb temperatures) change depending on the location and time of the year, effect of air conditions on cooling tower variables is investigated by selecting three possible locations for the power plant. Monthly average wet bulb and dry bulb temperatures at these locations are extracted from the ASHRAE climatic design conditions software (http://ashrae-meteo.info/) and presented in Table 4.

Table. 4. Monthly average ambient air conditions at the selected locations

Chicago, IL

\begin{tabular}{|c|c|c|c|c|c|c|c|c|c|c|c|c|}
\hline Data & Jan & Feb & Mar & Apr & May & June & July & Aug & Sep & Oct & Nov & Dec \\
\hline$T_{\text {wbt }}\left({ }^{\circ} \mathrm{C}\right)$ & 4 & 5.3 & 11.7 & 15.6 & 20.11 & 22.7 & 24.8 & 24.1 & 21.6 & 16.9 & 12.8 & 6.6 \\
\hline$T_{d b t}\left({ }^{\circ} \mathrm{C}\right)$ & 5.4 & 7.5 & 15.4 & 20.7 & 24.3 & 28.1 & 30.1 & 28.3 & 25.6 & 20.6 & 15.0 & 8.3 \\
\hline
\end{tabular}

Las Vegas, NV

\begin{tabular}{|c|c|c|c|c|c|c|c|c|c|c|c|c|}
\hline Data & Jan & Feb & Mar & Apr & May & June & July & Aug & Sep & Oct & Nov & Dec \\
\hline$T_{\text {wbt }}\left({ }^{\circ} \mathrm{C}\right)$ & 11.9 & 13.1 & 14.6 & 16.3 & 19.8 & 22.5 & 23.8 & 23.5 & 22.3 & 17.9 & 14.6 & 11.3 \\
\hline$T_{d b t}\left({ }^{\circ} \mathrm{C}\right)$ & 16.6 & 21.8 & 27.4 & 31.7 & 37.8 & 39.5 & 39.2 & 37.1 & 32.1 & 30.8 & 22.1 & 16.9 \\
\hline
\end{tabular}

Idaho Falls, ID

\begin{tabular}{|c|c|c|c|c|c|c|c|c|c|c|c|c|}
\hline Data & Jan & Feb & Mar & Apr & May & June & July & Aug & Sep & Oct & Nov & Dec \\
\hline$T_{\text {wbt }}\left({ }^{\circ} \mathrm{C}\right)$ & 3.8 & 6.6 & 8.8 & 11.8 & 15.2 & 17.8 & 20.2 & 19.1 & 17.1 & 12.3 & 8.9 & 4.8 \\
\hline$T_{d b t}\left({ }^{\circ} \mathrm{C}\right)$ & 6.1 & 10.7 & 16.1 & 23.8 & 26.2 & 29.3 & 30.2 & 30.1 & 26.4 & 22.5 & 12.6 & 7.5 \\
\hline
\end{tabular}

Monthly variation of the requirements at each of these locations for optimum design condition $\left(\dot{m}_{w} / \dot{m}_{a}\right)$ are shown in Fig. 3 for the AFR-100 power plant and reference 
water conditions mentioned in Table 1. It can be seen that the required tower volume, total power consumption, and make-up water requirements are all highest for the month of July at all the locations. Comparing these plots to the wet bulb data in Table 4, it can be concluded that the requirements are higher for higher wet bulb temperatures which explains why power consumption and total required volume are smaller in Las Vegas compared to Chicago for the month of July. The cooling tower should be designed for the maximum requirements and hence, results reported throughout are for the month of July. Calculations are performed for all three locations mentioned here but only the results from Idaho Falls are reported from hereon.
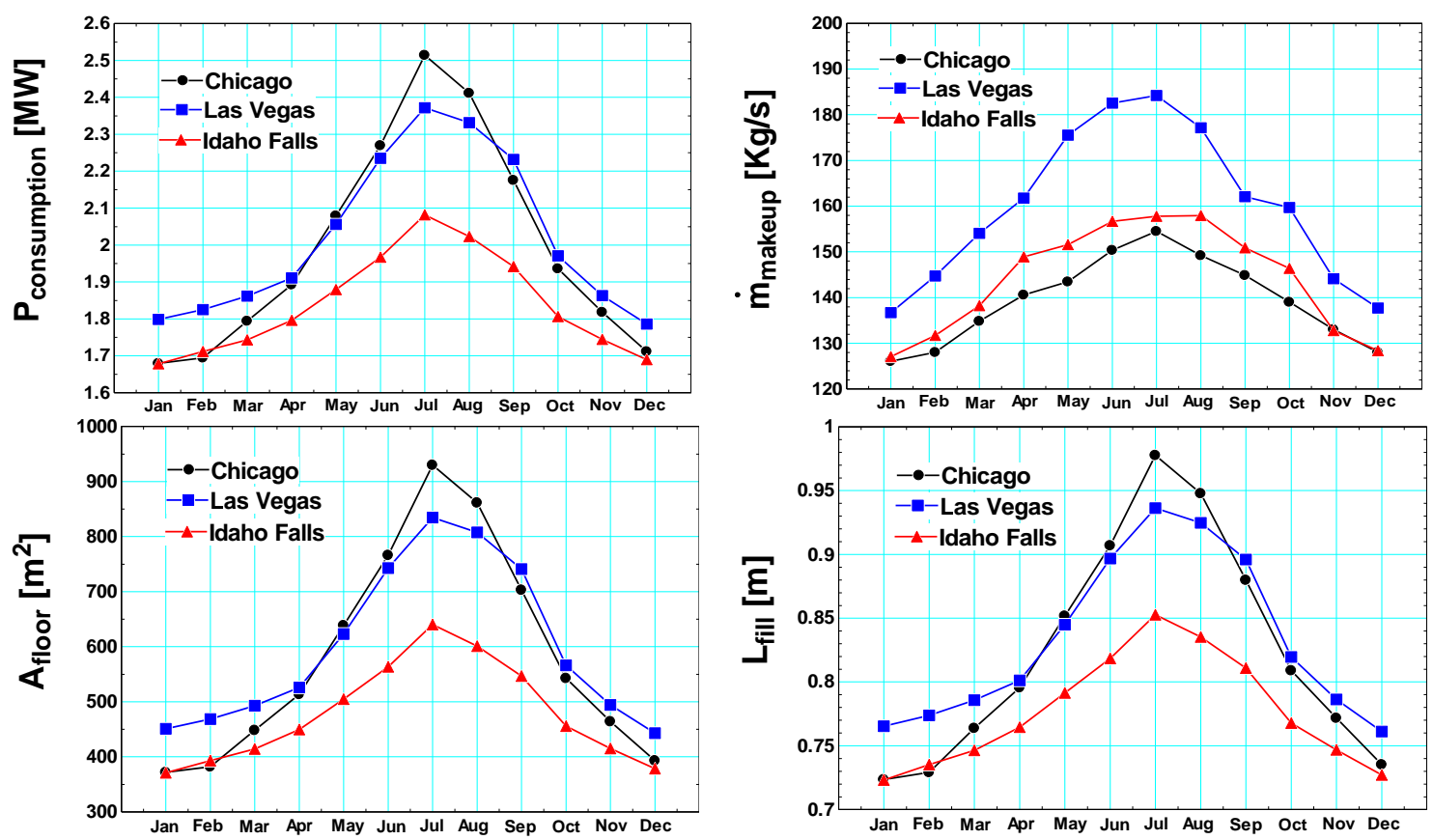

Fig. 3. Effect of ambient air conditions on the cooling tower requirements at reference water conditions for AFR-100 plant

As mentioned earlier $\mathrm{S}-\mathrm{CO}_{2}$ Brayton cycle achieves higher efficiency due to the fact that it exploits the high density of $\mathrm{CO}_{2}$ near the critical point to reduce the compressor work. Hence, it is extremely important to maintain the water temperature and flow rate at 
design conditions in order to achieve the desired cycle efficiency. This can be achieved by either adjusting the air flow rate or water flow rate per cell or combination of both depending on the changing ambient air conditions.

\section{Effect of design water conditions}

Calculations presented in the previous section were for the reference water conditions. However, for a fixed heat load, infinite combinations of water temperature and mass flow rate are possible. In this section, effect of changing the water temperature and flow rate combination on design of the cooling tower as well as the cooler is explained.

\section{Effect of water conditions on the cooler parameters}

ANL Plant Dynamics Code is used for the cooler calculations and the effect of water flow rate and temperatures on the cooler design is presented in Fig. 4.
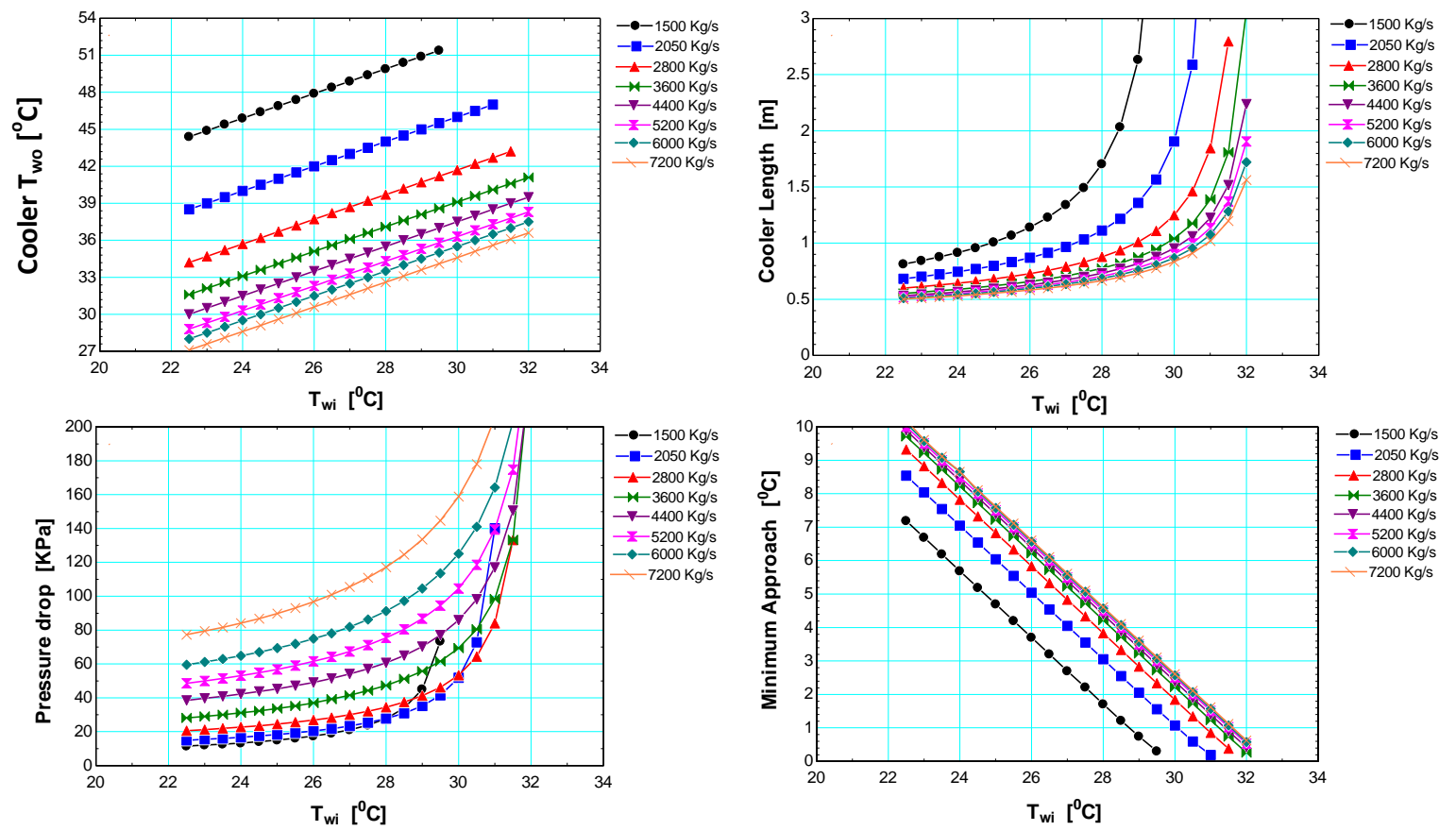

Fig. 4. Effect of water flow rate and temperature on the cooler parameters 
In Fig. 4 it should be noted that minimum possible water flow rate and temperature were selected as $1,500 \mathrm{~kg} / \mathrm{s}$ and $22.5^{\circ} \mathrm{C}$ respectively. Due to corrosion issues, range of the tower (defined as the temperature difference between water entering and leaving the tower) is recommended to be less than $22^{\circ} \mathrm{C}$ by the manufacturer, and this limits the lowest possible water flow rate to $1,500 \mathrm{~kg} / \mathrm{s}$ for an AFR-100 plant with a heat load of 137.2 MW. Also, the approach of the cooling tower (defined as the temperature difference between water leaving the tower and air wet bulb temperature) is recommended to be greater than $2.2^{\circ} \mathrm{C}$ to avoid pinch point kind of phenomenon in the cooling tower. This restricts the minimum water temperature to $22.5^{\circ} \mathrm{C}$ in Idaho Falls as per the wet bulb temperature data shown in Table. 4. Water inlet and outlet temperatures are related according to Equation (26) and hence, irrespective of the water flow rate the slope of equation is always equal to 1 . However, the intercept of the equation is inversely proportional to the water flow rate and decreases asymptotically as evident from Fig. 4.

$$
Q_{\text {load }}=\dot{m}_{w} C_{p w}\left(T_{\text {wo }}-T_{w i}\right)
$$

This asymptotical behavior is also reflected in the required cooler length and minimum approach (defined as the minimum temperature difference between hot and cold streams) plots. It should be noted that required cooler length starts to increase asymptotically as the water inlet temperature get close to the $\mathrm{CO}_{2}$ outlet temperature in the cooler. Similar behavior is observed for the water pressure drop as it is proportional to the cooler length and water flow rate. It is also important to understand the effect of water conditions on cooler cost to study the plant economics. The proposed coolers for 
the $\mathrm{S}-\mathrm{CO}_{2}$ Brayton cycle use Heatric printed circuit heat exchanger (PCHE) technology and are fabricated in stainless steel 316 (SS316) blocks which are welded together. The total cost of the cooler is calculated by adopting the following procedure suggested by Moisseytsev et al. [18],

1) The volume of each PCHE block is calculated from the Plant Dynamics Code and the total material required to fabricate the block is calculated as,

$$
\text { Mass }_{\text {block }}=\text { Volume }_{\text {block }} \cdot \rho_{s s 316}\left(@ 20^{\circ} \mathrm{C}\right)
$$

2) The cost of SS316 as per the current market is taken as $8.48 \$ / \mathrm{kg}$ and the total material cost of one PCHE block is calculated.

3) The fabrication cost to chemical etch the channels and perform diffusion bonding is assumed to be $\$ 48,480$ per block.

4) The total cost of each block is the sum of material cost and the fabrication cost and the total cost of the cooler is calculated as,

$$
\text { Cost }_{\text {cooler }}=\text { Cost }_{\text {block }} N_{\text {blocks }}
$$

Where, $N_{\text {blocks }}$ is the number of blocks and is be fixed as 72 for AFR-100 and 288 for ABR-1000 plants in the present analysis. Fig. 5 shows how the cooler cost changes with the water conditions for an AFR-100 plant and these results are independent of the location as the ambient air conditions have no influence on cooler design. At this point it is important to note that the cost of cooler has a similar trend to the cooler length as it is the only variable during the PDC calculations under the assumptions described above. 


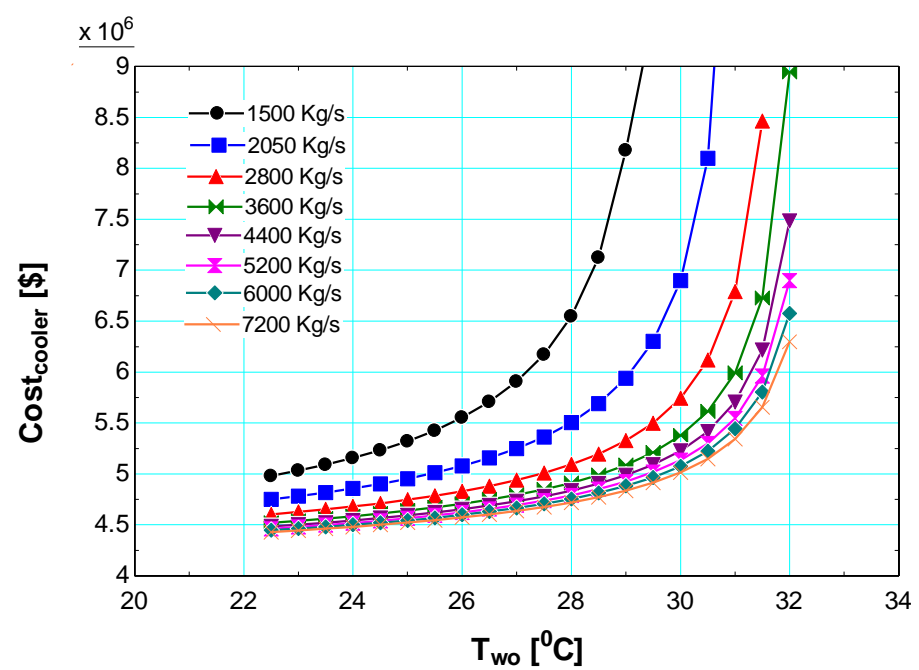

Fig. 5. Effect of water flow rate and temperature on the cooler cost

Effect of water conditions on the cooling tower parameters

As mentioned earlier, changing the water flow rate and temperature will also affect the size, power consumption and cost of the cooling tower. Fig. 6 shows the effect of water flow rate and temperature on the cooling tower parameters for lowest power consumption option assuming that power plant is setup in Idaho Falls. For constant ambient air and water conditions, the optimum $\dot{m}_{w} / \dot{m}_{a}$ calculated from Equations (4) and (5) is constant irrespective of the water flow rate. Hence, as the water flow rate decreases the required volumetric flow rate of air decreases leading to a total reduction of floor area $\left(A_{\text {floor }}\right)$ as can be seen in Fig. 6. Obviously, the required floor area increases as the cold water temperature approaches the wet bulb temperature as is evident from these plots. Fig. 6 also present the fill height calculations and it can be seen that the required fill height increases with decrease in water outlet temperature. This is exactly opposite to the effect of water temperature on cooler length from Fig. 5. 

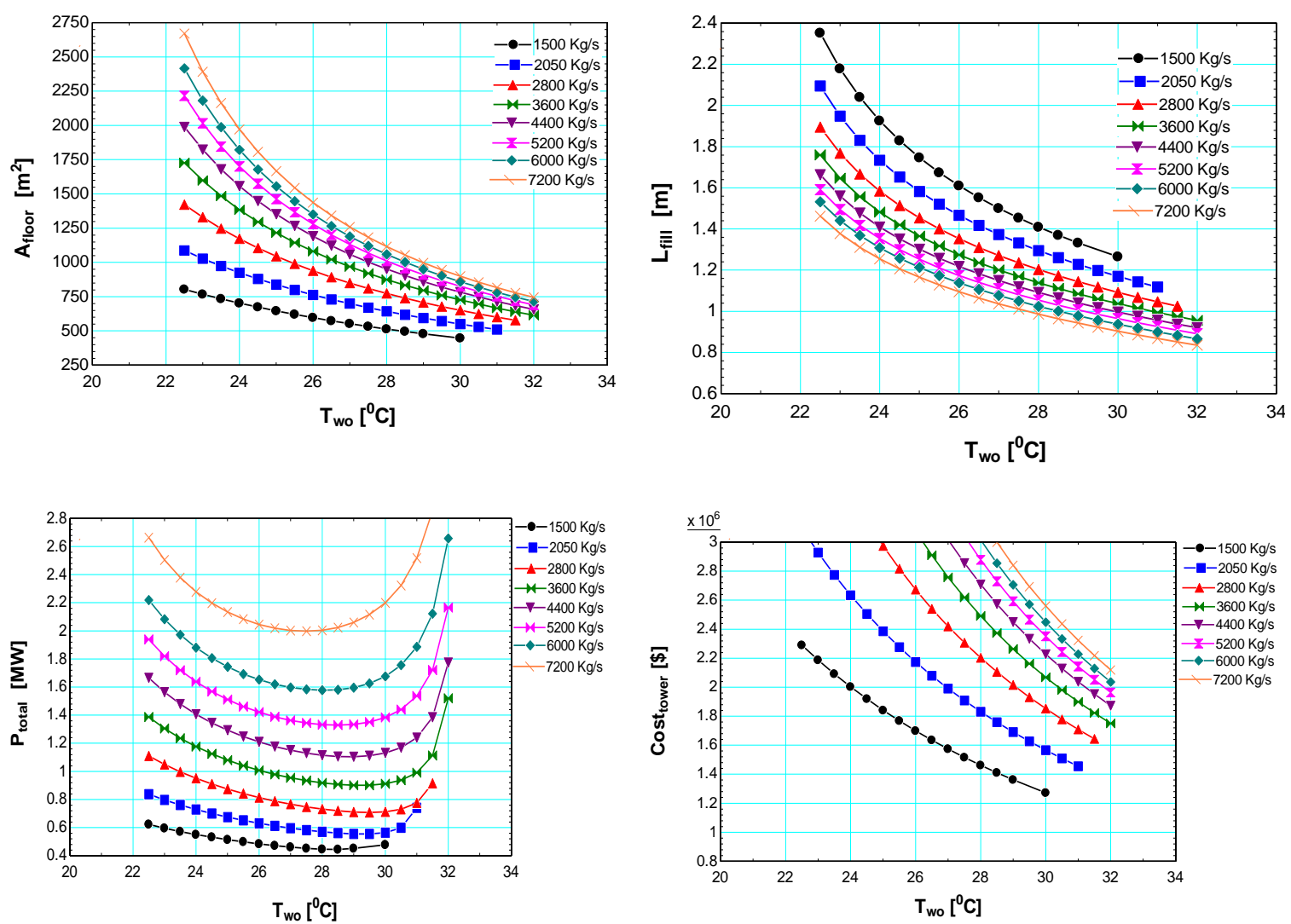

Fig. 6. Effect of water flow rate and temperature on the cooling tower parameters

This is due to the fact that an increase of approach in the cooler leads to a decrease in the approach of the cooling tower and vice versa. However, the effect of water flow rate on the fill height is similar to what has been observed in the case of the cooler as the overall driving enthalpy decreases with decrease in flow rate. From Fig. 6, it is also clearly evident that there is an optimum water temperature for each water flow rate that results in minimal power consumption. This is expected because a decrease of pumping head in the cooler will lead to an increase of pumping head in the cooling tower as explained earlier. Although the results presented in Fig. 6 are for Idaho Falls, similar conclusions can be drawn about other locations as well. The only difference observed was that the optimum water temperature tend to move towards hotter 
conditions as the ambient air wet bulb temperature increases as concluded later in Table. 5.

\section{Lowest power consumption vs lowest footprint option}

Fig. 7 compares the required floor area, power consumption for lowest footprint and lowest power consumption options. It can be noted that the required floor area for lowest power consumption option is significantly higher compared to lowest footprint option for all the water conditions.

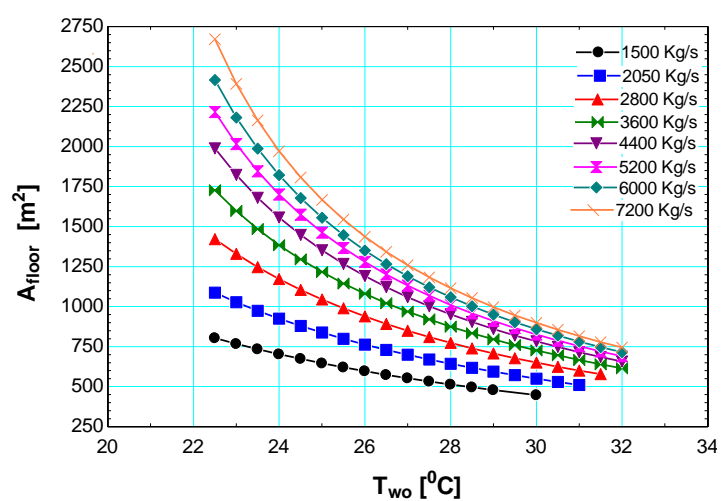

Lowest power consumption option

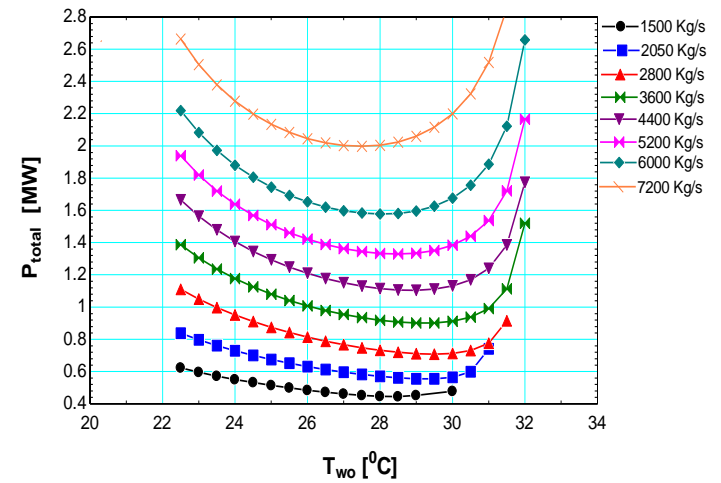

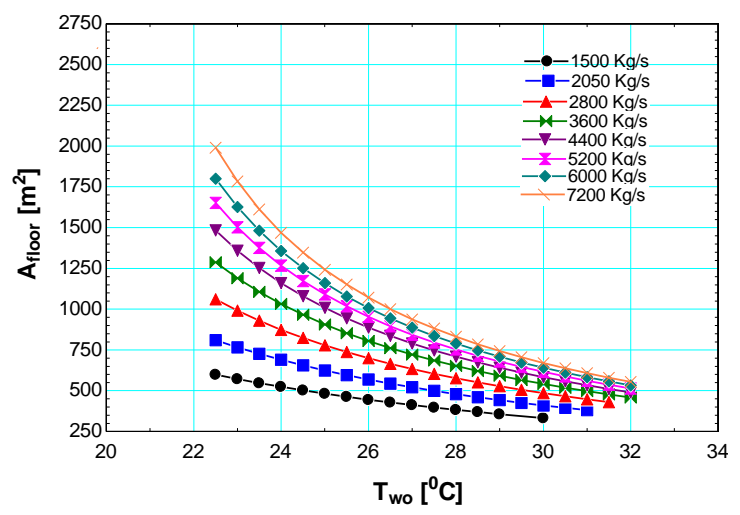

Lowest footprint option

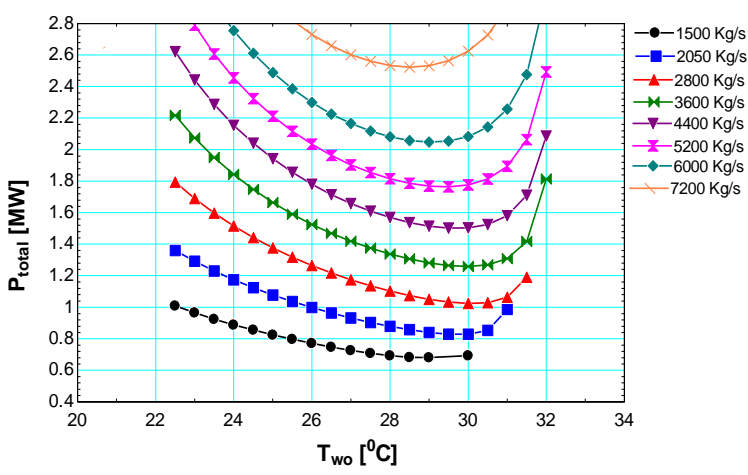

Fig. 7. Comparison of lowest power consumption and lowest footprint options

Although not presented here, similar trend is observed when comparing the required fill height and the cost of cooling tower for both the options. However, the total power consumption for lowest footprint option is significantly higher compared to the lowest power consumption option and will decrease the overall cycle efficiency. Therefore, it is 
important to understand which option is more economical to the cycle by performing an optimization study which takes into account both the plant capital cost and net power consumption.

\section{Cost-based optimization}

In the previous sections it has been concluded that the water conditions which reduce the cost of cooler tend to increase the cost of the cooling tower and vice versa. Also, any attempt to reduce the total cost of cooling tower and cooler tend to increase the total power consumption. This section explains the cost-based optimization method employed to understand the plant economics and the results obtained from this study. Previously, cost analysis was performed for the $\mathrm{S}-\mathrm{CO}_{2}$ Brayton cycle components by Moisseytsev et al. [18]. Each component capital cost was compared to the rest-of-theplant capital cost and the effect on the plant capital cost per unit net electrical output $\left(\$ / K W_{e}\right)$ is investigated for different water conditions. Several assumptions were made for this procedure and are kept consistent with the previous studies [1], [18]. These assumptions are listed as follows,

1) The capital cost of the plant, including the cooler and cooling tower, is assumed to be equivalent to $5,395 \$ / \mathrm{KW}_{\mathrm{e}}$ for reference water conditions, month of July in Chicago, and lowest footprint option.

2) The capital cost of the plant, excluding the cooler and cooling tower, is calculated for the reference conditions mentioned above and is assumed to be constant for all other conditions and locations. This value is calculated to be $5,192 \$ / K_{e}$ for AFR100 and 5,204 \$/KW for ABR-1000 plant. 
With these assumptions, the plant capital cost per unit electrical is calculated as,

$$
\frac{\$}{K W_{e}}=\frac{\text { Rest of plant capital cost }+ \text { Cooling tower cost }+ \text { Cooler cost }}{P_{\text {elec }}-P_{\text {pump }}-P_{\text {blower }}}
$$

This optimization technique is a powerful tool and allows for the plant optimization using any plant component as the variable. Fig. 8 compares the capital cost calculations for lowest footprint and lowest power consumption options for AFR-100 plant in Idaho Falls. Not surprisingly, there is an optimum water temperature for each flow rate which results in minimal plant capital cost. Interestingly, the plant capital cost is smaller for the lowest power consumption option compared to the lowest footprint option although it requires a larger cooling tower area. This indicates that it is more economical to have large number of smaller cooling cells which reduces the total power consumption. It also seems like the optimum water temperature for the lowest footprint option is slightly higher than the lowest power consumption option.

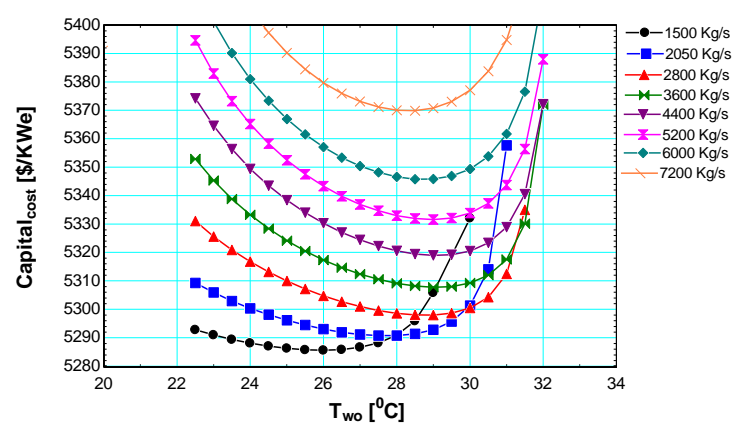

Lowest power consumption option

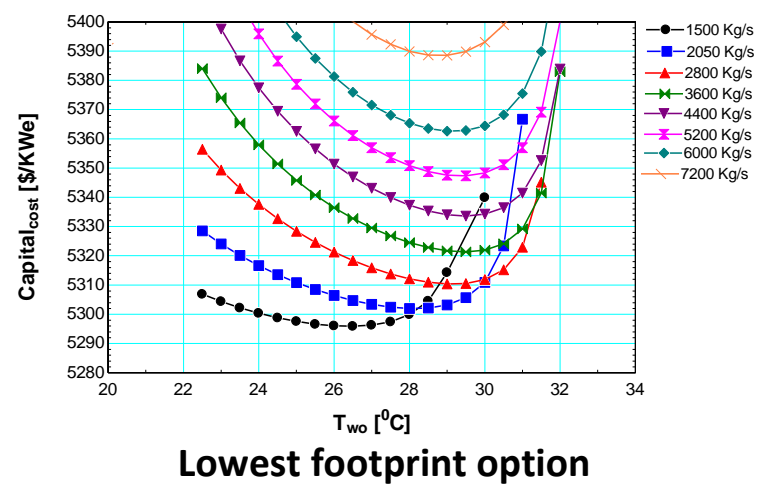

Lowest footprint option

Fig. 8 Effect of water conditions on AFR-100 plant capital cost in Idaho Falls

Similar conclusions can be drawn for other locations as well and are summarized in Table 5. 
Table 5. Summary of Cost-based optimization results for AFR-100 plant

\begin{tabular}{|c|c|c|c|}
\hline Location & Chicago & Las Vegas & Idaho Falls \\
\hline Number of cells & 53 & 52 & 46 \\
\hline Water mass flow rate $[\mathrm{kg} / \mathrm{s}]$ & 1,500 & 1,500 & 1,500 \\
\hline Water inlet temperature $\left[{ }^{\circ} \mathrm{C}\right]$ & 48.86 & 48.36 & 47.86 \\
\hline Water outlet temperature $\left[{ }^{\circ} \mathrm{C}\right]$ & 27 & 26.5 & 26 \\
\hline Wet bulb temperature $\left[{ }^{\circ} \mathrm{C}\right]$ & 24.88 & 23.88 & 20.22 \\
\hline Floor area $\left[\mathrm{m}^{2}\right]$ & 685.1 & 675.7 & 596.5 \\
\hline Fill height $[\mathrm{m}]$ & 2.219 & 2.056 & 1.61 \\
\hline Blower power $[\mathrm{MW}]$ & 0.3984 & 0.3841 & 0.3391 \\
\hline Pump power $[\mathrm{MW}]$ & 0.1757 & 0.1655 & 0.1446 \\
\hline Peak water consumption $[\mathrm{kg} / \mathrm{s}]$ & 126.1 & 144.1 & 130 \\
\hline Cooler PCHE volume $\left[\mathrm{m}^{3}\right]$ & 34.78 & 31.86 & 29.55 \\
\hline Cooling tower cost $[\$] \times 10^{6}$ & 1.951 & 1.925 & 1.699 \\
\hline Cooler cost $[\$] \times 10^{6}$ & 5.98 & 5.71 & 5.553 \\
\hline Plant capital cost $\left[\$ / \mathrm{KW}_{\mathrm{e}}\right]$ & 5,296 & 5,293 & 5,286 \\
\hline
\end{tabular}

It can be seen that the plant capital cost and optimum water temperature are highest in

Chicago of all the locations. This concludes that the plant capital cost and optimum water temperature will increase as the ambient air wet bulb temperature increases. Changing the water operating conditions from reference conditions $\left(6,000 \mathrm{~kg} / \mathrm{s}, 30^{\circ} \mathrm{C}\right)$ to optimum conditions $\left(1,500 \mathrm{~kg} / \mathrm{s}, 26^{\circ} \mathrm{C}\right)$ in Idaho Falls reduced the plant capital cost from $5,350 \$ / \mathrm{KW}_{\mathrm{e}}$ to $5,286 \$ / \mathrm{KW}_{\mathrm{e}}$. This corresponds to 6.7 million dollars reduction in total plant cost and goes on to show the importance of this optimization study.

\section{Comparison of cooling options}

As explained in the introduction section, there are multiple ways to reject heat from the $\mathrm{S}-\mathrm{CO}_{2}$ Brayton cycles. These cooling options are compared in Table 6. The data for dry air cooling and direct water cooling options was obtained from Moisseytsev et al. [1] for 
an ABR-1000 plant. Hence, the cooling tower optimization was performed for ABR-1000 plant for a direct comparison to the data of Moisseytsev et al. [1].

Table 6. Comparison of different cooling options for ABR-1000 plant

\begin{tabular}{|c|c|c|c|}
\hline Cooling option & $\begin{array}{c}\text { Direct water } \\
\text { cooling }\end{array}$ & Dry air cooling & Cooling tower \\
\hline Fluid flow rate $[\mathrm{kg} / \mathrm{s}]$ & 12,000 & 30,000 & 6,200 \\
\hline Peak water consumption rate $[\mathrm{kg} / \mathrm{s}]$ & 12,000 & - & 540.8 \\
\hline Cooler water inlet temperature $\left[{ }^{\circ} \mathrm{C}\right]$ & 30 & 30 & 25.5 \\
\hline Cooler water outlet temperature $\left[{ }^{\circ} \mathrm{C}\right]$ & 41.34 & 49.7 & 47.44 \\
\hline $\mathrm{CO}_{2}$ compressor inlet temperature $\left[{ }^{\circ} \mathrm{C}\right]$ & 31.25 & 40 & 31.25 \\
\hline $\mathrm{CO}_{2}$ compressor inlet pressure $[\mathrm{MPa}]$ & 7.4 & 8.864 & 7.4 \\
\hline Cycle efficiency $[\%]$ & 40.26 & 38.05 & 40.26 \\
\hline Blower power $[\mathrm{MW}]$ & - & 24.04 & 1.459 \\
\hline Pump power $[\mathrm{MW}]$ & 0.7843 & - & 0.6097 \\
\hline Cooler PCHE volume $\left[\mathrm{m}^{3}\right]$ & 126.7 & 3290.4 & 113.6 \\
\hline Heat rejection cost $[\$] \times 10^{6}$ & 22.7 & 603.4 & 29.21 \\
\hline Plant capital cost $\left[\$ / \mathrm{KW}_{\mathrm{e}}\right]$ & 5,271 & 7,670 & 5,304 \\
\hline
\end{tabular}

Clearly, direct water cooling option has the least plant capital cost per unit electrical output. However, the water consumption rate is $12,000 \mathrm{~kg} / \mathrm{s}$ and it is not always possible to meet such high water demand, especially at locations where the water resources are scarce. Even if the water resources are abundant, there are stringent environmental policies in place to prevent dumping of hot water into water bodies. It should be noted that water flow rate of $12,000 \mathrm{~kg} / \mathrm{s}$ reported in the table is found to be the optimum value for the direct water cooling option and water inlet temperature of $30^{\circ} \mathrm{C}$. Moisseytsev et al. [1] investigated the dry air cooling as a replacement for the direct water cooling option. For reference compressor inlet conditions (7.4 MPa, $31.25^{\circ} \mathrm{C}$ ), it has been realized that in order to have a reasonable power consumption of about $5 \%$ of the plant output the cooler volume has to be increased by about 100 times 
compared to the water cooled PCHE. This is primarily due to the fact that the specific heat of air and $\mathrm{CO}_{2}$ are quite different. The size of PCHE can be reduced by increasing the minimum $\mathrm{CO}_{2}$ temperature in the cooler. This will force to increase the compressor inlet pressure as well to take advantage of high density $\mathrm{CO}_{2}$ along the pseudo-critical line. Optimization by Moisseytsev et al. [1] indicated that increasing the minimum $\mathrm{CO}_{2}$ temperature to $40^{\circ} \mathrm{C}$ is beneficial for air cooling. Unfortunately, even for the optimized conditions mentioned in Table 6, the plant capital cost and power consumption are significantly higher compared to the direct water cooling option. Hence, from Table 6 it is clear that the cooling tower option is a much more feasible option compared to the dry air cooling. When compared to the direct water cooling option, there is about $\sim 1 \%$ increase in the plant capital cost per unit electrical output but only at a small fraction of the water consumption. It should be noted that there is still scope for optimization (changing compressor inlet conditions, cooler channel dimensions, etc.) as far as the cooling tower option is concerned and can be performed as future extension to this work.

\section{CONCLUSIONS}

A simplified one dimensional code was developed to investigate the option of using counter flow induced draft cooling tower to reject heat from $\mathrm{S}-\mathrm{CO}_{2}$ Brayton cycles. The calculations from the code are verified against a manufacturer quotation for specific conditions. To understand the effect of ambient air conditions three different locations were selected and calculations performed concluded that the tower size and power consumption increase as the wet bulb temperature of ambient air increases. Effect of 
water flow rate and temperature on design of cooler and cooling tower was investigated. It was found out that for a given water flow rate there exists a water temperature that results in minimal power consumption. A cost-based optimization method was employed to identify the optimum water conditions that would result in least plant capital cost per unit net electrical output. These calculations indicated that it is more economical to the plant to use certain number of small cooling cells rather than a single large cooling cell. For optimized conditions, direct water cooling, cooling tower, and dry air cooling options were compared and it can be safely concluded that the cooling tower is a more feasible and economical option compared to the dry air cooling option. Moreover, using a cooling tower instead of direct water cooling would increase the plant capital cost per unit electrical output by only 1\% but at a much lower water consumption.

\section{ACKNOWLEDGMENT}

This work was funded by the US Department of Energy Nuclear Energy University Programs (NEUP) project NEUP 12-3318 and NEUP 11-3039.

\section{NOMENCLATURE}

$\begin{array}{ll}a_{f i} & =\text { Area density of the fill }\left(\mathrm{m}^{2}\right) \\ A_{\text {floor }} & =\text { Floor area of the cooling tower }\left(\mathrm{m}^{2}\right) \\ A_{\text {cell }} & =\text { Floor area of a cooling tower cell }\left(\mathrm{m}^{2}\right) \\ B & =\text { Blowdown water losses }(\mathrm{kg} / \mathrm{s})\end{array}$


Nuclear Engineering and Design

\begin{tabular}{|c|c|c|}
\hline$C_{p m a}$ & $=$ & Specific heat of moist air $(\mathrm{J} / \mathrm{kg}-\mathrm{K})$ \\
\hline Cost $_{\text {tower }}$ & $=$ & Cost of the cooling tower $(\$)$ \\
\hline Cost $_{\text {cooler }}$ & $=$ & Cost of the cooler $(\$)$ \\
\hline Cost $_{\text {cell }}$ & $=$ & Cost of each cooling tower cell (\$) \\
\hline Cost $_{\text {block }}$ & $=$ & Cost of each PCHE block (\$) \\
\hline$E$ & $=$ & Evaporation water losses $(\mathrm{kg} / \mathrm{s})$ \\
\hline$C_{p w}$ & $=$ & Specific heat of water (J/kg-K) \\
\hline$g$ & $=$ & Acceleration due to gravity $\left(\mathrm{m} / \mathrm{s}^{2}\right)$ \\
\hline$G_{a}$ & $=$ & Mass flux of air $\left(\mathrm{kg} / \mathrm{m}^{2}-\mathrm{s}\right)$ \\
\hline$G_{w}$ & $=$ & Mass flux of water $\left(\mathrm{kg} / \mathrm{m}^{2}-\mathrm{s}\right)$ \\
\hline$h_{d}$ & $=$ & Mass transfer coefficient $(\mathrm{m} / \mathrm{s})$ \\
\hline$H_{\text {tower }}$ & $=$ & Cooling tower water pumping head (m) \\
\hline$H_{\text {cooler }}$ & $=$ & Cooler water pumping head $(\mathrm{m})$ \\
\hline$H_{p}$ & $=$ & Net water pumping head $(\mathrm{m})$ \\
\hline$i_{m a}$ & $=$ & Enthalpy of moist air $(\mathrm{J} / \mathrm{kg})$ \\
\hline$i_{\text {masw }}$ & $=$ & Enthalpy of moist air at saturated conditions $(\mathrm{J} / \mathrm{kg})$ \\
\hline$i_{w}$ & $=$ & Enthalpy of water (J/kg) \\
\hline$L_{\text {fill }}$ & $=$ & Height of the fill zone $(\mathrm{m})$ \\
\hline
\end{tabular}




\begin{tabular}{|c|c|c|}
\hline$L_{r z}$ & $=$ & Height of the rain zone $(\mathrm{m})$ \\
\hline$L_{s p}$ & $=$ & Height of the spray zone $(\mathrm{m})$ \\
\hline Le & $=$ & Lewis factor $\left(h_{c} / C_{p m a} h_{d}\right)$ \\
\hline Me & $=$ & Merkel number \\
\hline Mass $_{\text {block }}$ & $=$ & Mass of each PCHE block (kg) \\
\hline$\dot{m}_{w}$ & $=$ & Mass flow rate of water $(\mathrm{kg} / \mathrm{s})$ \\
\hline$\dot{m}_{a}$ & $=$ & Mass flow rate of dry air $(\mathrm{kg} / \mathrm{s})$ \\
\hline$\dot{m}_{\text {makeup }}$ & $=$ & Total water consumption rate in the cooling tower $(\mathrm{kg} / \mathrm{s})$ \\
\hline$N_{\text {cells }}$ & $=$ & Number of cells in a cooling tower \\
\hline$N_{\text {blocks }}$ & $=$ & Number of blocks in a PCHE \\
\hline$P_{\text {pump }}$ & $=$ & Water pumping power (W) \\
\hline$P_{\text {blower }}$ & $=$ & Air blower power (W) \\
\hline$P_{\text {consumption }}$ & $=$ & Total power consumption (W) \\
\hline$P_{\text {elec }}$ & $=$ & Net electrical output of the cycle (W) \\
\hline$Q_{\text {load }}$ & $=$ & Heat rejection load (W) \\
\hline$\dot{Q}_{a o}$ & $=$ & Volumetric flow rate of air leaving the cooling tower $\left(\mathrm{m}^{3} / \mathrm{s}\right)$ \\
\hline$T_{w}$ & $=$ & Water temperature $\left({ }^{\circ} \mathrm{C}\right)$ \\
\hline$T_{w i}$ & $=$ & Water temperat \\
\hline
\end{tabular}




$$
\begin{array}{ll}
T_{w o} & =\text { Water temperature leaving cooler/entering cooling tower }\left({ }^{\circ} \mathrm{C}\right) \\
T_{w b t} & =\text { Wet bulb temperature of ambient air }\left({ }^{\circ} \mathrm{C}\right) \\
T_{d b t} & =\text { Dry bulb temperature of ambient air }\left({ }^{\circ} \mathrm{C}\right) \\
T_{a o} & \text { Optimum temperature of air leaving cooling tower }\left({ }^{\circ} \mathrm{C}\right) \\
\text { Volume } e_{b l o c k} & =\text { Volume of each PCHE block }\left(\mathrm{m}^{3}\right) \\
W & =\text { Drift water losses }(\mathrm{kg} / \mathrm{s})
\end{array}
$$

Greek Symbols

$$
\begin{array}{ll}
\rho_{a 0} & =\text { Density of air leaving the cooling tower }\left(\mathrm{kg} / \mathrm{m}^{3}\right) \\
\rho_{s s 316} & =\text { Density of stainless steel } 316\left(\mathrm{~kg} / \mathrm{m}^{3}\right)
\end{array}
$$

\section{Subscripts/Superscripts}

$$
\begin{array}{ll}
\text { Ipco } & =\text { Lowest power consumption option } \\
\text { Ifo } & =\text { Lowest footprint option }
\end{array}
$$

\section{REFERENCES}

[1] Moisseytsev, A., and Sienicki J. J., "Investigation of a dry air cooling option for an S$\mathrm{CO}_{2}$ cycle." The 4th International Symposium - Supercritical $\mathrm{CO}_{2}$ Power Cycles, Pittsburgh, PA, September 9-10, 2014.

[2] Heatric Division of Meggitt (UK) Ltd., 2014, http://www.heatric.com/

[3] Moisseytsev, A. and Sienicki, J. J., "Supercritical Carbon Dioxide Brayton Cycle for SFR Applications: Optimization, Transient Analysis, and Control," IAEA-CN-199/180, 
Proceedings of International Conference on Fast Reactors and Related Fuel Cycles: Safe Technologies and Sustainable Scenarios, FR-13, Paris, France, March 4-7, 2013.

[4] Sienicki, J. J., Moisseytsev, A., and Krajtl, L., "Utilization of the Supercritical $\mathrm{CO}_{2}$ Brayton Cycle with Sodium-Cooled Fast Reactors," The 4th International Symposium Supercritical $\mathrm{CO}_{2}$ Power Cycles, Pittsburgh, PA, September 9-10, 2014

[5] Moisseytsev, A., and Sienicki, J. J., Development of a plant dynamics computer code for analysis of a supercritical carbon dioxide Brayton cycle energy converter coupled to a natural circulation lead-cooled fast reactor. Argonne National Laboratory, Argonne, IL (United States). Funding organization: US Department of Energy (United States), 2007.

[6] Qureshi, Bilal A., and Syed M. Zubair. "A complete model of wet cooling towers with fouling in fills." Applied Thermal Engineering 26, no. 16 (2006): 1982-1989.

[7] Simpson, W. M., and T. K. Sherwood. "Performance of small mechanical draft cooling towers." Refrigerating Engineering 52, no. 6 (1946): 525-543.

[8] Merkel, Friedrich. Verdunstungskühlung. VDI-Verlag, 1925.

[9] Kloppers, Johannes C., and Detlev G. Kröger. "The Lewis factor and its influence on the performance prediction of wet-cooling towers." International Journal of Thermal Sciences 44, no. 9 (2005): 879-884.

[10] Kloppers, Johannes C ., and Detlev G . Kröger. "Cooling tower performance evaluation: Merkel, Poppe, and e-NTU methods of analysis." Journal of Engineering for Gas Turbines and Power 127, no. 1 (2005): 1-7.

[11] Klein, S. A., and F. L. Alvarado. "Engineering equation solver." F-Chart Software, Madison, WI (2002).

[12] Delta Cooling Towers, Inc., 2014, http://www.deltacooling.com/

[13] Leeper, Stephen A. Wet cooling towers: rule-of-thumb design and simulation. No. EGG-GTH-5775. EG and G Idaho, Inc., Idaho Falls (USA), 1981.

[14] Lilly, Dana Elizabeth. "Analysis and performance of gas-electric hybrid chiller systems." (1998).

[15] Kloppers, J. C., and D. G. Kröger. "Refinement of the transfer characteristic correlation of wet-cooling tower fills." Heat transfer engineering 26, no. 4 (2005): 035041. 
Nuclear Engineering and Design

[16] Kröger, Detlev G. Air-cooled heat exchangers and cooling towers. Vol. 1. PennWell Books, 2004.

[17] Zanker, A. "Estimating Cooling Tower Costs from Operating Data." CHEMICAL ENGINEERING 79, no. 13 (1972): 118.

[18] Moisseytsev, A., and Sienicki, J. J., "Cost-Based Optimization of Supercritical Carbon Dioxide Brayton Cycle Equipment." Transactions of the American Nuclear Society 105 (2011): 675-676. 